\title{
A Comparative Study Between TPS (Think-Pair-Share) And Jigsaw Techniques to Enhance Students' Reading Comprehension Ability
}

\author{
Glory Destiny Biantice Marpaung ( P.T. Purwadhika Kirana Nusantara, BSD City, \\ Tangerang Selatan) \& Nelson Balisar Panjaitan (Universitas Advent Indonesia, \\ Bandung). Correspondence author (nelsonpandjaitan@gmail.com)
}

\begin{abstract}
The purpose of this study is to find out the enhancement of students' reading comprehension between those who were taught using TPS (Think-PairShare) technique and those who are taught using the Jigsaw technique. The study discussed the recent developments in reading pedagogy. This study used a quantitative research method and comparative design by measuring the achievement of pre-test and post-test. The result of this study shows that p.value $(\mathrm{sig})=0.187>\alpha(0.05)$. Therefore, it is concluded that there is no significant difference in the student's reading comprehension ability. Even the difference is not significant, based on the mean score of the classes before and after being taught using those techniques, this study indicates that the use of Think-PairShare and Jigsaw can enhance students' reading comprehension ability. The study also provides a new interpretation of existing sources on teaching method and offers new insights of teaching reading method by emphasizing collaborative learning.
\end{abstract}

Keywords: TPS (Think-Pair-Share) and Jigsaw

\section{Introduction}

Reading comprehension ability is essential for success in acquiring a second language. It is the basis of instruction in all aspects of language learning such as in using textbooks for language courses, writing, revising, editing, and using computer-assisted language learning programs (Mikulecky, 2008).

According to Rosen (2017), if a learner wants to learn a new language quickly, lots of reading is important. The more the learners read, the brain will input more about how the language works. Learners can also enhance vocabulary, grammar, and writing skills at the same time by reading. Concerning the importance of reading, Graesser et. al (2011) also added, students who want to learn the English language quickly must learn by reading plentifully in English.

There is a survey about reading behaviors among nations over the world conducted by The World's Most Literate Nations (WMLN) in 2016. WMLN made ranks nations on 
literate behaviors. The survey showed that Indonesia ranked 60th out of 61 countries in terms of reading interest. The fact is very contradicting with Indonesian Curriculum. The skill of reading Bahasa and also English text as part of the subject are taught since the students studied in Elementary school. "In the case of Indonesians, there is a high level of acceptability and tolerance of the use of English. The teaching of English in the school curriculum is given a higher priority over all other foreign languages in the school systems". Thus, the teaching of English as a Foreign Language (EFL) is in fact compulsory (katemba,2013). However, as Indonesian students, they have already encountered problems with reading comprehension in Indonesian, the language that they've acquired and learned, they also find it way more difficult to read and comprehend reading in English, the foreign language that they do not acquire and learn it barely for a short time (Siagian \& Katemba, 2016)

In searching the effective methods, teachers take a complex role. Teachers have to make their teaching both interesting and relevant to their students. In order to reach the students and teach them something, it is vital to teach in a relevant manner, opening up for student participation, and consider all the different individuals in the classroom (Hansen, 2016).

Teachers can promote this confidence building by providing small steps for success. Many instructors have found that through peer instruction, students teach each other by addressing misunderstandings and clarifying misconceptions (Chandra, 2015). Some experts assured cooperative learning was one of the effective ways and has been shown to have positive effects on various outcomes (Cambria and Guthrie, 2010).

Cooperative learning makes a non-threatening environment where students freely mix with each other without any racial discrimination (Millis, 2002). Based on that opinion learning with cooperative models can be applied to motivate students to dare to express opinions, appreciate the opinions of friends, and mutual provide opinions or sharing ideas. Therefore, cooperative learning could be very good to be implemented because students can work together and help each other to overcome the task faced and have improved their reading comprehension (Katemba \& Samuel (2017), Pertiwi (2015).

In fact, there are a lot of techniques in cooperative learning. Among all of the techniques in cooperative learning, the researcher gives attention to Think-Pair-Share and Jigsaw technique. Based on the explanation, the researcher decided to conduct an experimental study entitled "A comparative study between TPS (Think-Pair-Share) and Jigsaw techniques to enhance students' reading comprehension ability".

Referring to the statement of the research problem above, the objective of the research is to find out whether there is a significant difference to enhance students' reading comprehension ability after being taught by using Think-Pair-Share technique and Jigsaw technique.

Null Hypothesis (Ho): There is no significant difference between those who are taught using TPS and those who are taught using JIGSAW in terms of enhancing students' reading comprehension. 
Alternative Hypothesis (Ha): There is a significant difference between those who are taught using TPS and those who are taught using JIGSAW in terms of enhancing students' reading comprehension.

\section{Literature review}

Reading Comprehension

The main concept in reading skill is comprehension (Keshavarzi, 2015). Duke's study (as cited in Gilakjani 2016) found a process in which readers make meaning by interacting with text through the combination of previous experience, information in the text, and readers' view is called comprehension. Readers who can read accurately and effectively to get the knowledge and information from the text with minimum misunderstand is a reader who has reading comprehension skill (Khruawan and Dennis, 2017).

Purpose of Reading

People read written materials for different purposes. The ability to read the text in any form will bring them many great advantages (Romli, 2014). Conforming to Adetoro (2010), the reader can address individuals' needs by reading. It is also can reduce the ambiguity in their surroundings, give them solutions to problems they encounter, make them survive in difficult circumstances, as well as to enhance their personal growth.

\section{Teaching Reading}

As reported by Andriani (2016), comprehension is the ultimate goal of reading. Students must have a passion for reading. They should read a lot and must be able to orchestrate multiple strategies before, during, and after reading. In line with Harvard's study (as cited in Gurk 2016) found out that cooperative learning techniques as one of the teaching methods which have a big effect on students' reading comprehension. Cooperative learning can be used by the teacher as an instructional technique in teaching reading comprehension.

Cooperative Learning

Conforming to Mandal (2006), cooperative learning environment refers to a situation which learners with one common cause in their mind who strive to achieve one common learning goal. Mandal and Willing (2009) stated cooperative learning for students such as cooperative learning develops higher level thinking skills, creates a good learning environment.

The notion of Think-Pair-Share (TPS)

The Think-Pair-Share technique is a Cooperative Learning discussion technique introduced in 1981 by Frank Lyman and his team of educators in Maryland, USA. It is a learning strategy that is developed to encourage student classroom participation. 


\section{Notion of Jigsaw}

Jigsaw is cooperative learning which emphasizes students to work in the form of a small group. Inayati (2011) affirmed that the development of jigsaw is a way to build a classroom as a community of learners, so all students are valued. The participant is acknowledged that they are valuable participants in the ongoing organizational tasks of finding and solving problems.

\section{Methodology}

Research Design and Method

This research used a quantitative research method with comparative design. This kind of design compares the students' grade before and after the treatment which has been given in both experimental groups.

Table 1. Research Design

\begin{tabular}{|c|c|c|c|}
\hline GROUP & PRE-TEST & TREATMENT & POST-TEST \\
\hline 1 & $\mathrm{O}$ & $\mathrm{X} 1$ & $\mathrm{O}$ \\
\hline 2 & $\mathrm{O}$ & $\mathrm{X} 2$ & $\mathrm{O}$ \\
\hline
\end{tabular}

Explanation:

X1: Learning English by Think-Pair-Share Technique

X2: Learning English by Jigsaw Technique

$\mathrm{O}$ : Reading Comprehension

Participants

There are two classes of the seven grader students in SMP Advent Cimindi, Bandung. This research employed those two classes as the experimental class. The sample is Grade VII A \& grade VII B. The population consisted of 45 students.

The Instrument

The research instrument truly determined the result of the research activity. In this study, the researcher gave 50 questions as a pilot test to grade VIII students of SMP Advent Cimindi. After that, the researcher constructed a pre-test based on the result of the pilot test. The pre-test was administered to both sample groups from grade VIII. The two groups of samples had different treatment. One group studied were taught using ThinkPair-Share technique, and the other group was taught using the Jigsaw technique. After the treatment, the researcher gave a post-test for the two groups. The post-test was the same as the pre-test.

Data gathering and procedures

In gathering the data, the researcher used the following steps: 


\section{Preparation Stage}

In this study, the researcher did a preliminary study in which to get the picture of the research sample. Then the researcher prepared the research instrument, lesson plan for 8 meetings and asked the permission letter from the dean of the UNAI Education Faculty to conduct the research.

Data Collection

The data was collected with several steps below:

\section{A. Conducting a Pilot test}

There were 50 questions in this test. The test was administered to VIII students in the school. After collecting the data, the researcher analyzed the data with Anates Program.

\section{B. Conducting Pre-test}

The pre-test was conducted in order to find out the students' reading comprehension before the treatment. There were 37 questions that were given to both groups. In this study, the pre-test measured the students' early reading material mastery in both experimental groups before giving the treatment.

\section{Giving Treatment}

Treatment was conducted after the pre-test has been administered. In this study, both groups were given treatment; however, the treatment was different between those two groups. The researcher used TPS and Jigsaw techniques to enhance the students' reading comprehension. The treatment was being held for one month to two sample groups in the grade VII SMP Advent Cimindi

\section{Treatment Procedure}

After administering the pre-test, the treatment was conducted to the students. The material was taken from the textbook prepared by the school and other materials from the internet. The procedure of TPS was adapted from Wahyuni and Badriyah (2015) and Jigsaw procedure was adapted from Meng (2010).

\begin{tabular}{|l|l|}
\hline $\begin{array}{c}\text { The procedure of using Think-Pair- } \\
\text { Share technique }\end{array}$ & \multicolumn{1}{c|}{$\begin{array}{c}\text { The procedure of using Jigsaw } \\
\text { technique }\end{array}$} \\
\hline $\begin{array}{l}\text { Step 1 Determining what is } \\
\text { important }\end{array}$ & $\begin{array}{l}\text { Step 1 Determining what is } \\
\text { important }\end{array}$ \\
$\begin{array}{l}\text { 1. The researcher will explain the } \\
\text { material } \\
\text { before the students read the story. }\end{array}$ & $\begin{array}{l}\text { 1. The researcher will explain the } \\
\text { material } \\
\text { before the students read the story. }\end{array}$ \\
\hline
\end{tabular}




\begin{tabular}{|c|c|}
\hline $\begin{array}{l}\text { 2. Students listen to the explanation } \\
\text { and take notes to write the } \\
\text { important things from the materials. } \\
\text { Step } 2 \text { Reading Exercise } \\
\text { 1. The researcher will distribute each } \\
\text { student the same story based on the } \\
\text { material. } \\
\text { 2. The students read silently the } \\
\text { reading the passage for } 10 \text { minutes. } \\
\text { During this period, students reading } \\
\text { individually before they share their } \\
\text { idea with their pair. } \\
\text { 3. Teachers may choose whether to } \\
\text { assign pairs or let students pick their } \\
\text { own partner. Individuals' pair up } \\
\text { and exchange thoughts for } 20 \\
\text { minutes. }\end{array}$ & $\begin{array}{l}\text { 2. Students listen to the explanation } \\
\text { and take notes to write the } \\
\text { important things from the materials. } \\
\text { Step 2 Reading Exercise } \\
\text { 1. The researcher will distribute the } \\
\text { story that has already been chunked } \\
\text { (each } \\
\text { students in the group get different } \\
\text { passage with their team. } \\
\text { 2. Students will take a turn to read the } \\
\text { story. Students must read based on } \\
\text { his/her 'chuck' passage. (around } \\
\text { 15minutes) } \\
\text { 3. Students consult with another } \\
\text { expert from other teams. Experts } \\
\text { return to their teams and teach } \\
\text { another member based on what } \\
\text { they have discussed. }\end{array}$ \\
\hline
\end{tabular}

\section{Step 3 Conclusion}

Teacher asks one student from each group to present their thoughts, ideas, and questions they had to the rest of the class.

\section{Step 3 Conclusion}

Teacher asks the student to present their thoughts, ideas, and questions they have to the rest of the class. The pairs are given 30 minutes to share their responses with others group.

\section{E. Conducting Post-test}

After conducting the treatment, the post-test was administered. It is done in order to know the students' reading comprehension after being given the treatment. The purpose of conducting the post-test is to find out whether there is any significant difference in students' reading comprehension achievement between the two groups. The researcher used questions from pre-test as the post-test.

Statistic procedure

The researcher used the statistical treatment in analyzing the data. The statistical analysis in this research has been done by computing the data using several statistical calculations through the SPSS 23 program and Anates program.

Data Analysis on Pilot Test

Before the treatment, the pilot test was conducted which consisted of 50 
multiple-choice questions to measure the validity and reliability of the instruments.

\section{A. Validity}

According to Setiyadi (2006), validity is used to measure perception, language behavior, motivation, even language comprehension. A valid instrument has high validity. The instrument could be called valid if it can show the data of variable which are researched correctly. The validity test was to find out whether the instrument test is suitable to be used in this research or not.

B. Reliability Test

According to Erman (2003) the reliability of a tool that finds out the result that is consistent in using the same subject. Formula: $r_{-} 11=(n /(n-1))\left(1-\left(\sum^{2}{ }_{i} S_{-}{ }^{\wedge}{ }^{\wedge} 2\right) /\left(S_{-}{ }^{\wedge} 22\right)\right)$

\section{Discriminating Power Index}

Discriminating power index is to clarify the difference between good students (high ability) and the students who were less (low ability) based on their answer in the test.

\section{Difficulty index}

After constructing, administering on the sample test, and scoring test, then difficulty index was analyzed. A good question is a question that is used to determine the level of difficulty of that question. Test items of a wide range of difficulty levels were needed to test the entire range of candidates' achievement levels.

\section{E. The Result of Recapitulation of Pilot Test}

This research used 37 questions in pre-test and post-test. To analyze the result of the data the Anates was used.

Null Hypothesis (Ho): There is no significant difference between those who are taught using TPS and those who are taught using JIGSAW in terms of enhancing students' reading comprehension.

Alternative Hypothesis (Ha): There is a significant difference between those who are taught using TPS and those who are taught using JIGSAW in terms of enhancing students' reading comprehension.

\section{Data of Test Result}

To examine the null and alternative hypothesis, the researcher used a t-test to prove whether the null hypothesis is accepted or rejected. The researcher used Statistical Package Service Solution (SPSS) to analyze the statistical result.

Before the items were used as pretest and posttest, the researcher made the pilot test first to find out the quality of the items, whether they are reliable and valid. The pilot 
test was conducted at SDN Karyawangi Parongpong Bandung. 29 students participated in answering the test.

\section{Findings and discussion}

The result of pre-test and post-test of each group was calculated through excel and SPSS 23. It can be seen in the following table:

Table 2

\begin{tabular}{|c|c|c|c|c|}
\hline \multirow{2}{*}{} & \multicolumn{2}{|c|}{ Think-Pair-Share } & \multicolumn{2}{c|}{ Jigsaw } \\
\cline { 2 - 5 } & Mean & St. Deviation & Mean & St. Deviation \\
\hline Pre-test & 62.0455 & 8.73677 & 67.0952 & 9.74117 \\
\hline Post-test & 72.0909 & 6.63977 & 75.1905 & 7.66563 \\
\hline Normalized Gain & 0.94250 & 0.602122 & 0.69914 & 0.585091 \\
\hline
\end{tabular}

From the table 2 it can be seen the mean pre-test of TPS group is 62.0455 with St. Deviation 8.73677 and post-test 72.0909 with St. Deviation 6.63977. For Jigsaw group, the mean of the pre-test is 67.0952 with St. Deviation 9.74117 and post-test 75.1905 with St. Deviation 7.66563. Based on the increase of the mean and decrease of St. Deviation from pre-test to post-test of both groups, it can be concluded that there is an enhancement on students' reading comprehension ability.

Test of Normality

The researcher used the test of normality to observe the probability distribution of the data. The result of the normality can be seen on the table:

Table 3 Normality Test

\begin{tabular}{|c|r|r|r|}
\hline \multirow{2}{*}{ Group } & \multicolumn{3}{|c|}{ Shapiro-Wilk } \\
\cline { 2 - 4 } & Statistic & \multicolumn{1}{c|}{ df } & \multicolumn{1}{c|}{ Sig. } \\
\hline TPS &, 926 & 22 &, 099 \\
Jigsaw &, 911 & 21 &, 057 \\
\hline
\end{tabular}

According to the table above, this research used the output from the Shapiro Wilk because is the powerful normality test, as written by Razali and Wah (2011). If both data have $\mathrm{p}$. Value ( $\mathrm{sig})>\alpha=0.05$ it means the data is normally distributed and if the $\mathrm{p}$. Value (sig) $<\alpha=0.05$ it means the data is not normally distributed. Based on the data above, the data was normally distributed. It is because the significant score of gain for TPS was $0.099>0.05$ and the significance of the normalized gain for JIGSAW was $0.057>0.05$. 
Test of Homogeneity of Variance

To see the homogeneity of population variances, the homogeneity test was done. The result of the homogeneity test can be seen in the table below:

Table 4 Homogeneity of Variance

\begin{tabular}{|r|r|r|r|}
\hline Levene Statistic & df1 & df2 & \multicolumn{1}{c|}{ Sig. } \\
\hline, 859 & 1 & 41 &, 360 \\
\hline
\end{tabular}

The data is homogenous if p.value (sig) $>\alpha=0.05$ it means data is homogenous and if $p$.value ( $\mathrm{sig})<\alpha=0.05$ it means data is not homogenous. The result between TPS and JIGSAW were homogenous. It is because sig $(0.360)>\alpha=0.05$.

Hypothesis Testing

According to table 4.3 above the result of the data was normally distributed, therefore the researcher used Independent Sample t-test.

The researcher set two assumptions to know the hypothesis is accepted or not:

1. If, $\rho . v a l u e ~(s i g) \leq \alpha(0.05)$ : Ho is rejected. It means there is a significant difference in the students' reading comprehension ability between those who were taught using TPS and those who are taught using JIGSAW?

2. If $\rho . v a l u e$ ( $\mathrm{sig}) \geq \alpha(0.05)$ : Ho is not rejected. It means there is no significant difference in the students' reading comprehension ability between those who were taught using TPS and those who are taught using JIGSAW?

The result calculation can be seen on the following table below:

\section{Table 5 Independent Sample Test}

\begin{tabular}{|c|c|c|c|c|c|}
\hline & \multicolumn{2}{|c|}{$\begin{array}{c}\text { Levene's Test for } \\
\text { Equality of Variances }\end{array}$} & \multicolumn{4}{|c|}{} & $\begin{array}{c}\text { Sig. (2- } \\
\text { tailed) }\end{array}$ \\
\cline { 2 - 6 } & $\mathrm{F}$ & Sig. & $\mathrm{t}$ & $\mathrm{df}$ &, 187 \\
\hline $\begin{array}{c}\text { Equal variances } \\
\text { assumed } \\
\begin{array}{c}\text { Equal variances not } \\
\text { assumed }\end{array}\end{array}$ &, 655 &, 423 & 1,343 & 41 &, 186 \\
\hline
\end{tabular}

The result of the data above in table 4.4 showed that $\rho$.value sig, $=0.187>\alpha$ (0.05). It means that Ho is not rejected. Therefore, it is concluded that there is no significant difference in the student's reading comprehension enhancement between those who were taught through TPS and JIGSAW. According to the data above, the researcher 
used the data of equal variances assumed which concern that the sample data was distributed homogenous and sig (2-tailed).

\section{Discussion of the Research Findings}

From the result of the data, it showed that there is no significant difference in students' reading comprehension between those who were taught using Think Pair Share and those who were taught using Jigsaw. Even though there is no significant difference, the data from the Think-Pair-Share class and Jigsaw class showed that the student reading enhancement increased. It can be seen from pre-test score for TPS technique 62.0455 to post-test score 72.0909 and pre-test Jigsaw technique 67.0952 to post-test score 75.1905. It can be concluded that both techniques are applicable and good, proven by the data previously discussed

The researcher assumes in implementing different techniques in teaching, it contributes to the development of students' skills, knowledge, and achievement. Cooperative learning is one of the innovative pedagogies that has been found to be positively effective on students' reading comprehension ability. It can help students to break the ice when generally it is the traditional lecture-dominant pattern. Students need to have peer support not only to learn the material at a deeper level but also to know their classmates and to build a sense of community with them.

The research findings show that the use of the Think-Pair-Share technique and Jigsaw technique was able to enhance the students' reading comprehension ability even there was no significant difference. The students were happy and enjoyed reading using those techniques. They liked to have a discussion with their friends. By having discussions, the students were able to have a better understanding of reading texts than before. Their cooperation was also getting better. It implied that the English teacher can use the technique more often in order to get a better understanding to comprehend the text and better cooperation with their pair or group.

Furthermore, English teacher can use that technique to overcome some problems that might arise during the group works. The English teacher should also be creative in using interesting activities in order to attract the students' involvement in the teaching and learning process.

\section{Summary}

The purpose of this study is to find out whether there is any significant difference between students who were taught through Think-Pair-Share and those who were taught Jigsaw in enhancing English reading comprehension. This study is comparative research. In this research design, the pre-test was conducted before giving the treatment. After the 
treatment, the researcher gave the post-test to find out the enhancement of students' reading comprehension.

The participants of this study were the pupils of SMP Advent Cimindi, Bandung. They were divided into 2 groups. Group 1 (Grade 7a) Group 2 (Grade 7b) which consisted of a total of 43 students. The researcher used SPSS 23 to calculate the data. After calculating the data by using SPSS 23, there is no significant difference in gain mean score between TPS and Jigsaw. It means the researcher used Independent Sample T-test to answer the hypothesis testing.

From the data analysis and hypothesis testing, it was concluded: That there was no significant difference between those who were taught through TPS and those who were taught Jigsaw.

\section{Conclusion}

From the result of data analysis on the pre-test and post-test, the researcher concluded that there is no significant difference between those who were taught using TPS and those who were taught using Jigsaw. From TPS group on the pre-test, it was 62.04 with a standard deviation of 8.73 and the post-test was 72.09 with a standard deviation of 6,63. Based on the TPS data which showed that the gain for mean was 0.94250 with standard deviation 0.602122. JIGSAW pre-test was 67.09 with a standard deviation of 9.741 and the post-test 75.190 , with a standard deviation of 7.665 based on the Jigsaw data showed that the gain for mean 0.69914 with a standard deviation of 0.585091 .

\section{Recommendation}

Based on the findings, the researcher gave several recommendations as follow:

1. For Teachers:

Teachers can use these two methods as an alternative to teaching English reading because the students will become active and interested in reading.

2. For Students:

For students, it is recommended to learning English reading comprehension using these methods, because they are interesting methods and less stressful.

3. For Future Researchers

The researcher hoped that the result of this study can be used as an additional reference for a future researcher in different levels and contexts.

\section{References}

Adetoro, N. (2010). Reading Interest And Information Needs of Persons with Visual Impairment in Nigeria. South African Journal of Libraries and Information. 
Andriani, D. (2016). The Influence of Reading Comprehension Achievement at The Eighth Grade Students of SMP Muhsammadiyah 1 Rawa Bening by using DRTA And KWL Strategies. TELL-US JOURNAL.

Cambria, J., \& Guthrie, J. T. (2010). Motivating and engaging students in reading. The NERA Journal, 46(1), 16-29.

Chandra, R. (2015). Collaborative Learning for Educational Achievement. IOSR Journal of Research \& Method in Education (IOSR-JRME).

Duke, N. (2003). Comprehension Instruction for Informational Text. Presentation at the Annual Meeting of The Michigan Reading Association, Grand Rapids, MI.

Gilakjani, A. (2016). How Can Students Improve Their Reading Comprehension Skill? Journal of Studies in Education.

Graesser et al. (2011). Using Virtual Agents to Deliver Lessons in Reading Comprehension to Struggling Adult Learners.

Gurk, N. K. (2016). The Effect of Cooperative Learning Techniques on Intermediate Iranian EFL Learners' Reading Comprehension And Reading Strategies. Journal of Studies In Education.

Hansen, E.J. (2016). Reading Comprehension.

Inayati, M. (2011). "The Effectiveness of Jigsaw Technique in Improving Students' Reading Comprehension".

Katemba, C.V. (2013), Anxiety Level of Indonesian Students and Its Relationship To Academic Achievement In English. Journal of Education and Practice Vol.4 No.27 pp. 1-9. Retrieved from http://www.iiste.org/Journals/index.php/JEP/article/view/9873/10097

Katemba, C.,V., \& Samuel (2017). Improving Student's Reading Comprehension Ability Using Jigsaw 1 Technique . Acuity : Journal of English Language Pedagogy, Literature and Culture Vol 2 No.2 2017. Retrieved from : http://jurnal.unai.edu/index.php/acuity/article/view/613/468

Keshavarzi, A. (2015). The Effect of Cooperative Learning on Reading Comprehension and Reading Anxiety of Pre-University Student.

Khruawan \& Dennis. (2017). A Study of English Reading Comprehension using Content-Based Instruction approach. International Journal Of ResearchGranthaalayah.

Mandal, R. (2006). Cooperative Learning Strategies to Enhance Writing Skill.

Mandal, R., \& Willing, L. (2009). Cooperative Learning Strategies to Enhance Writing Skill. The Modern Journal of Applied Linguistics, 1(2), 95-101. 
Mikulecky, B.S. (2008). Teaching Reading in a Second Language.

Millis, J., \& Cottell, G. (2002). Cooperative Learning for Higher Education Faculty. Phoenix, AZ. Oryx Press.

Romli, M. (2014). Improving The Students' Reading Comprehension of Narrative Text Through Story Mapping.

Siagian, S., W., \& Katemba, C., V., (2016). Comparative Study

Between Think Aloud and Visual Imagery in Enhancing Students' Reading Comprehension. Acuity Journal of English Language Pedagogy, Literature and Culture Voll no.1 2016. Retrieved from:

http://jurnal.unai.edu/index.php/acuity/article/view/602 